\title{
Work Environment and Compensation on Nurse's Job Satisfaction and Its Implication on Extra Role Behavior in Efarina Etaham Hospital, Purwakarta
}

\author{
Bertie Riyestavani \\ Sentul Pertamedika Hospital \\ Yusuf Arifin \\ Master of Management, University of Pasundan \\ yusufarifin@yahoo.com
}

\begin{abstract}
This study aims to obtain empirical evidence about the effect of work environment and the compensation on nurse's job satisfaction and its implications on extra role behavior in Efarina Etaham Hospital, Purwakarta. The method used was descriptive and verificative analysis. The data collection was an interview by using a questionnaire along with observation techniques. The population is 70 nurses. Field data collection was conducted in 2014. Data were analyzed by path analysis. The results showed that work environment, compensation, job satisfaction, and extra role behaviors generally are relatively good. Meanwhile, the work environment and compensation partially and simultaneously have a positive and significant effect on job satisfaction. Job Satisfaction has positive and significant effect on extra role behaviour of nurses.
\end{abstract}

Keywords : work environment, compensation, job satisfaction, extra role behaviour

\section{INTRODUCTION}

In such service company like hospitals, role of human resources is indispensable because it is directly related to the satisfaction that will be felt by the customers/patients of the hospital (Sujudi, 2011). Demands of rapid development of hospitals need to be supported by many factors, one of which professional human resources so as to answer the challenges of an increasingly competitive business in the future.

Public demand good quality health services resulted in nurses must be willing to perform "extra" in addition to the basic tasks that must be done. The "extra" tasks such as willing to cooperate and help and willing to use their time effectively. Prosocial behavior or "extra" action that exceeds the organization's description of the role assigned is called organizational citizenship behavior (Organ, et.al., 2006).

In connection with the phenomenon in the field, the organizational citizenship behavior (OCB) employees at the Purwakarta Etaham Hospital is relatively low, as seen from the behavior of helping others (altruism) that nurses are rarely willing to replace colleagues who do not get in. Nurses also rarely take the time to help other nurses related to problems in the work nor take the time to help patients or visitors who need assistance, related to the caution (courtesy). Nurses also sometimes get disrespectful treatment in serving patients, rarely follow the changes in the organization, sometimes exaggerate the problem which took place in the organization, and is not open in admitting mistakes.

One of the main causes of nursing staff, nursing services and nursing shortage problems is the lack of job satisfaction. When there are many nurses who experience job dissatisfaction, it will impact on the poor hospital services. Gillies (1996) stated that job satisfaction is influenced by factors closely related to work environment such as organizational policies, relationships with superiors and co-workers, rewards, direct superior quality, and working conditions.

Positive environment in working in hospitals is able to influence, encourage and motivate someone to work optimally in accordance with the profession in order to reach satisfaction in work.

One indicator to indicate the level of satisfaction in hospitals is the level of turnover. The following data is on the number of nurses that resigned per year, the average number of nurses for one year, and the percentage of turnover of nurses in Efarina Etaham Purwakarta Hospital from 2008-2012.

The above data showed a high turnover of nurses who allegedly as a result of low job satisfaction. The high percentage of nurse turnover will cause damage to the hospital because obtaining new nurses require fees for the recruitment, selection, interviewing, and training and development of new nurses. To anticipate 
the lack of job satisfaction, it is necessary to analyze factors that affect job satisfaction of nurses at Efarina Etaham Purwakarta Hospital.

By devoting effort, time, knowledge and skills in an organization, one expects different types of remuneration or compensation. Based on interviews with HR regarding compensation components, we obtained information that components in the current system of financial compensation are considered to be too much. The nurses assess many components but the nominal is small so it motivated less and asked the nominal to be improved, and in addition the payroll staff has difficulty to calculate and distribute. This is because there are too many components of compensation, manual counting and the increasing number of employees.

Preliminary survey results showed that nurses at the Efarina Etaham Purwakarta Hospital complain about the low compensation that have been received so far. Complaints are often submitted to their superiors. The result showed high turnover of staff, especially among paramedics.

Based on Table 1, it is known that there are 14 people $(82.6 \%)$ who expressed dissatisfaction in payroll obscurity component, only $1(5.8 \%)$ who expressed dissatisfaction in the discomfort component. Factors that cause dissatisfaction among other things in terms of compensation applied by the company management. Compensation management does not assess to give an effect on the welfare of employees. In turn, it decreases employee motivation and this will lead to their productivity or performance to be below the company's standards, or they decide to leave the company.

\section{METHOD}

This research was conducted on nurses at the Efarina Etaham Purwakarta Hospital. The study was conducted on Jalan Raya Cibeuning Bungursari, Bungursari Purwakarta, West Java. The population in this study were 70 nurses at the Efarina Etaham Purwakarta Hospital.

Testing the hypothesis in this study will use Path Analysis based on regression analysis with the help of SPSS version 2.0. Path analysis model was used to analyze the relationship between variables in order to determine the direct or indirect effect, of a set of independent variables (exogenous) to the dependent variable (endogenous). Simultaneous testing is used by the F-Snedecor distribution with the error rate or level of significance $(\alpha)$ by 0.5 . To determine the influence of variable $\mathrm{Y}$ (job satisfaction) on variable $\mathrm{Z}$ (extrarole behavior), it uses the coefficient of determination.

\section{RESULT}

The working environment at the Etaham Purwakarta Hospital measured by the dimensions of the working environment both physical and non-physical showed an average of $63.5 \%$, which means that work environment in the Efarina Etaham Purwakarta Hospital could be interpreted in the category of quite good. Things that should get attention for improvement concerning physical work environment are air circulation, paint colors, temperatures, and unpleasant odors in the room. Things that should get attention for improvement concerning non-physical work environment are safety, and the opportunities provided by the hospital for a promotion at work.

Compensation in Efarina Etaham Purwakarta Hospital measured by the dimensions of financial and non-financial compensation showed that the average variable compensation amounted to $66.4 \%$, which can be interpreted in the category of quite good. Things that should get attention for improvement concerning financial compensation are the implemented pension plan, the incentive system applied, and the system of allowances applied. Things that should get attention for improvement concerning non-financial compensation are communication with the leaders, the challenges of work, superiors and subordinates at the hospital supporting smooth working, the treatment of leaders toward employees, and are guaranteed a good career.

Job satisfaction of nurses in Efarina Etaham Purwakarta Hospital are measured by dimensions of employment, salary and promotion, working conditions, colleagues and superiors, as well as compatibility between work and personality. It showed the average variable by $73.4 \%$, which means the job satisfaction of nurses in Etaham Purwakarta Hospital can be interpreted in the category of good. Things that still needs to be improved, namely salaries and promotions imposed by the current hospital, equipment that support the execution of the work, and the rewards given on the performance of nurse leaders.

Extra role behavior of the nurse in the Efarina Etaham Purwakarta Hospital with dimensions of behavior to help others (altruism), chariness (conscientiousness), awareness (civic virtue), sportsmanship, politeness (courtesy) showed the average variable by $82.2 \%$, which means extra role behavior of nurses at the Efarina Etaham Purwakarta Hospital can be interpreted in the category of good. Things that still need improvement are participation in activities/ events held by the hospital, take a good care for the local comuunity who may require assistance, optimization in creativity and initiative in carrying out the work, and the response when colleague suggested the problem and ask for suggestions to solve the problem.

The both hypothesis test results showed that the working environment and compensation effect on job satisfaction of nurses at the Hospital of Efarina Etaham Purwakarta is $68.23 \%$. This means that the working environment and compensation have a significant positive influence on job satisfaction of nurses. This 
illustrates that the level of the working environment and compensation perceived by nurse will determine the level of job satisfaction of nurses at Etaham Purwakarta Hospital.

Partial effect can be seen that the compensation with the value of $39.27 \%$ is the dominant influence of job satisfaction of nurses at the Efarina Etaham Purwakarta Hospital than work environment, and the effect of job satisfaction on the extra role behavior in Etaham Purwakarta Hospital is at $70.56 \%$.

These findings concur with those of Herzberg who, stated about the factors that bring satisfaction are achievement, recognition, work itself, responsibility, leadership, and progress (Armstrong, 2004: 71). Job satisfaction is closely linked to the attitude factor. As stated by Tiffin (1964) in As'ad (2005:105), job satisfaction is closely linked to the attitude of employees toward work itself, the work situation, the cooperation between the leadership with fellow employees. Correspondingly, Martoyo (2000: 142) stated that job satisfaction is an emotional state of employees where happens or does not happen a meeting point between the remuneration of employees of the company or organization to the level of the value of remuneration benefits that are desired by the employee. Employee's remuneration, either in the form of financial or nonfinancial.

Handoko in Asa'd (2005: 36) stated that job satisfaction is an assessment or a mirror of feelings of workers to work. Job satisfaction is a feeling associated with work involving aspects such as wages or salary received, career development opportunities, relationships with other employees, job placement, type of work, organizational structure, the quality of supervision. While the feeling that they relate to, among others, age, state of health, ability, education.

Robbins (2006: 251) and Luthans (2006: 132) reported job satisfaction has a positive relationship with performance, meaning high job satisfaction will improve employee performance. The relationship will be stronger if the employee is not influenced by external factors, such as a job that is highly dependent on the machine. Levels of working also affects to the power of relationship between job satisfaction and productivity. This study shows a strong association seen in employees with higher level of working, for example for managerial positions. According to Timpe translated by Sofyan (2004: 9), a person's performance can be affected by internal factors and external factors. Internal factors are factors originating from within or the employees themselves, such as attitude, behavior, and functional ability of social workers can affect the daily work. External factors are factors originating from employees environment. These factors can affect the ability and motivation of functional social workers.

Extra role behavior or Organization Citizenship Behavior (OCB) is an individual behavior that is "discretionary". It is not directly recognized by the formal reward system, and together will encourage the organization function more effectively (Organ, 2006). There is evidence that individuals who demonstrate OCB has a better performance (Podsakoff and MacKenzie, 1996). Behavior that goes beyond their job duties commonly referred to as outside role behavior (extrarole behavior). This behavior is very much appreciated when it is done by employees, although not formally descripted because it will improve the effectiveness and performance,

Many factors can form OCB, one of which the most important is job satisfaction. It is very logical statement which assumes that job satisfaction is a key determinant of OCB employees (Robbins, 2006). Employees who are satisfied are more likely to speak positively about the organization, help colleagues, and make their performance exceeded normal estimation. More than that, employees who are satisfied are more obedient to the call of duty, because they want to repeat their positive experiences (Robbins, 2006). Bateman and Organ (1983: 591) stated that all dimensions of job satisfaction such as work, co-workers, supervision, promotions, pay and overall positively correlated with OCB.

The results of both hypothesis test contained two variables that are working environment and compensation effect on job satisfaction of nurses at the Efarina Etaham Purwakarta Hospital. The magnitude of the effect of job satisfaction on the extra role behavior analysis is using the coefficient of determination, ie $70.56 \%$. Meanwhile the remaining $29.44 \%$ is explained by other variables not examined in this study.

The results of the verification analysis regarding the effect of work environment and compensation for job satisfaction are by $68.23 \%$. This illustrates that the level of the working environment and compensation perceived nurse will determine the level of job satisfaction of nurses at the Etaham Purwakarta Hospital. Partial effect can be seen that the compensation with the value of $39.27 \%$ is the dominant influence on job satisfaction of nurses at the Efarina Etaham Purwakarta Hospital than work environment.

The results of this study are consistent with the results of Herzberg's research which stated that the factors that bring satisfaction are achievement, recognition, work itself, responsibility, leadership, and progress (Armstrong, 2004:71). Many factors can form the OCB, one of which the most important is job satisfaction. It is very logical statement which assumes that job satisfaction is a key determinant of OCB employees (Robbins, 2006). Evidence that job satisfaction affect OCB is Bolon's research (1999). Bolon found that job satisfaction affects the two types of OCB namely OCB-I and OCB-O.

Evidence that job satisfaction is closely linked or influence OCB is Bolon's research (1999). Bolon found 
that job satisfaction affects the two types of OCB namely OCB-I and OCB-O. Wagner and Rush (2000), Yoon and Suh (2003), Begum (2005) and Fotee and Tang (2008) stated that this study found that job satisfaction is significantly influenced by OCB.

Nevertheless, there are still differences in the findings examining the relationship between job satisfaction and $\mathrm{OCB}$, as research conducted by Williams and Anderson (1991), which states that there are different effects on intrinsic and extrinsic job satisfaction of the two types of OCBs. Research by Ackfeldt and Coote (2000), found that there was no relationship between job satisfaction and OCB employees. Alotaibi (2001), found that job satisfaction has no effect on OCB workers in Kuwait. Kim (2006) found that job satisfaction has no effect on Altruism and Compliance, the dimensions of organization citizenship behavior (OCB). Therefore, it is very much still needed further research to examine the relationship between job satisfaction and OCB.

\section{CONCLUSION}

Working conditions in Efarina Etaham Purwakarta Hospital both the physical work environment and nonphysical work environment were relatively good. Aspects that still need to be improved, namely work environment includes air circulation, paint colors, temperatures, and unpleasant odors in the workspace; Non-physical work environment includes safety at work and promotion opportunities.

Compensation given by Efarina Etaham Purwakarta Hospital seen from financial compensation and nonfinancial compensation were relatively good. It still remains to be improved, namely financial compensation includes retirement programs, incentives, and allowances are applied; Non-financial compensation include communication with the leaders, the challenges of work, superiors and subordinates at the hospital supporting smooth working, the treatment led to subordinates, and guarantees a good career.

The condition of Efarina Etaham Purwakarta Hospital nurses' job satisfaction seen from the work itself, salary and promotion, working conditions, colleagues and superiors, as well as the suitability between work and personality were relatively satisfied. Things that still needs to be improved were the award by leaders for the achievements of employees, relationship between superiors and subordinates, and consideration of subordinates' proposal by the leaders.

Extra role behavior of nurses in Efarina Etaham Purwakarta Hospital seen from the behavior of helping others (altruism), chariness (conscientiousness), awareness (civic virtue), sportsmanship, politeness (courtesy) were relatively good. Things that still needs to be improved were the participation in the activities held by the Hospital, take a good care of the surrounding communities, optimization of creativitas and initiative in work, as well as response when a co-worker in trouble.

The influence of working environment and compensation simultaneously on job satisfaction of nurses at Efarina Etaham Purwakarta Hospital is 68.23\% with the remaining of $31.77 \%$ is influenced by other factors and is not examined such as leadership style and organizational culture. However, seen in partially compensation is the more dominant influence on job satisfaction of nurses with the amount of $39.27 \%$ than work environment, amounting to $28.96 \%$.

The influence of job satisfaction on extra-role behavior of nurses at Efarina Etaham Purwakarta Hospital is equal to $70.56 \%$ with a positive direction, where the better perceived job satisfaction, will result in increased on extra-role behavior of nurses.

\section{REFERENCES}

Ackfeldt and Coote, L. 2005. A Study of Organizational Citizenship Behaviours in a Retai Setting. Journal Busness Research 58 : $151-159$.

Alotaibi, Adam. 2001. Antecedents of Organizational Citizenship Behavior. A Study of Public. Personnel in Kuwait. Journal of Public Personnel Management $30(3): 363-376$.

Armstrong, Kotler.2004. Principles of Marketing, United State of America : Pearson Education.

As'ad M. 2005. Psikologi Islam Seri Sumber Daya Manusia. Yogyakarta : Liberty.

Bateman TS: Organ DW. 1983. Job Satisfaction and The Good Soldier. The Relationship between Affect and Employee "Citizenship" Academy. Journal Of Management 26: 587 - 595.

Begun, Noorjahan. 2005. The Relation between Social Power and Organizational Citizenship Behavior. The Meditational Role of Procedural Justice, Organizational Commitment and Job Satisfaction in Context of a Private Commercial Bank in Bangladesh.

Bolon, D., S. 1999. Level of Analysis Considerations in Organizational Citizenship Behavior Research : An empirical investigation of individual and work groups effects among hospital employess. Health Services Management Research 12 (2): 92 - 108. June.

Gillies, D. A. 1996. Nursing Management, A System Approach, Philadelphia : W.B. Sounders Company

Ivana First. 2009. Brand Meaning and its Creation in a Cross-Cultural Context. Dissertation pf the University of St. Gallen. www1.unisg.ch.

Kim, I.,-H., Muntaner C. Khang, Y, -H. 2006. The Relationship Between Nonstandard Working and Mental Health in A Representative Sample of The South Korean Population, Social Science \& Medicine, 63: 566-574.

Luthans, Fred, 2006. Perilaku Organisasi, alih bahasa 
Agus Dharma. Edisi Sepuluh, Penerbit ANDI, Yogyakarta.

Martoyo, Susilo. 2000. Manajemen Sumber Daya Manusia. BPFE. Yogyakarta.

Organ, Dennis W; Phillip Podsakoff; Scott B Mackenzie. 2006. Organizational Citizenship Behavior. Its Natue, Antecedents, and Consequences. Foundations for Organizational Science. SAGE Publications.Inc.

Podsakoff, P.M., Mac. Kenzie, S.B., and Bommer, W.H. 1996. Transformational leader behavior and substitutes for leadership as determinant of employee satisfaction, commitment, trust, and organizational citizenship behavior. Journal of Management, 22: 259 - 298

Robbins, Stephen P., 2006. Organizational Behaviour, Edisi Ke Sepuluh, Penterjemah Benyamin Molan, PT. Indeks Kelompok Gramedia.
Ruthankoon, R.; Ogunlana, S.O. 2003. Testing Herzberg's Two-Factor Theory in the Thai Construction Industry. Engineering, Construction and Archtectural Management. Vol. 10, Iss. 5; pg. $333-342$.

Suyudi, Achmad. 2011. Dari Pulau Buru ke Cipinang. Sebuah Sejarah Kecil. Rayyana Komunikasindo

Timpe, Dale. 2004. Kinerja (alih bahasa Sofyan). Jakarta : PT.Gramedia Asri.

Wagner, Shaon L and Rush, Michael C. 2000. Atruistic Organizational Behavior: Context, Dispositiom, and Age The Journal of Social Psychology; Jun 2000; 140, 3; Proquest Medical Library p. 379.

William LJ. Anderson, SE. 1991. Job Satisfaction and Organizational Commitment as Predictors of Organizational Citizenship and in-role Behavior. Journal of Management. 17 (3). $601-617$.

\section{APPENDIX}

Table 1. Data on Employee's Reasons Moving to Other Hospital or Other Places

\begin{tabular}{cllccc}
\hline \multirow{2}{*}{ No } & & \multirow{2}{*}{ Type of Employee } & \multicolumn{3}{c}{ Reasons of Moving } \\
\cline { 3 - 5 } & & Dedic & $0(0 \%)$ & Payroll Obscurity & Carrier Path \\
\hline 1 & Paramedic & $1(5,8 \%)$ & $1(5,8 \%)$ & $1(5,8 \%)$ \\
3 & Non medic & $0(0 \%)$ & $10(58,9 \%)$ & $1(5,8 \%)$ \\
\hline \multicolumn{2}{l}{ Total (\%) } & $1(5,8 \%)$ & $3(17,9 \%)$ & $0(0 \%)$ \\
\hline
\end{tabular}

Source : Pre Survey, (data processed by author, 2013)

Table 2. Percentage of Nurse Turnover in Efarina Etaham Purwakarta Hospital Year 2008 - 2012

\begin{tabular}{lccccc}
\hline \multicolumn{1}{c}{ Information } & $\mathbf{2 0 0 8}$ & $\mathbf{2 0 0 9}$ & $\mathbf{2 0 1 0}$ & $\mathbf{2 0 1 1}$ & $\mathbf{2 0 1 2}$ \\
\hline The number of nurses resign per year (person) & 15 & 14 & 16 & 13 & 15 \\
The number of nurses per year (person) & 80 & 85 & 78 & 75 & 70 \\
Turnover Percentage (\%) & 18,75 & 16,47 & 20,51 & 17,33 & 21,43 \\
\hline
\end{tabular}

Source : Etaham Purwakarta Hospital Nurse Data, 2013

Table 3. Variable Operationalization

\begin{tabular}{|c|c|c|c|c|}
\hline $\begin{array}{c}\text { Variable and } \\
\text { Variable Concept }\end{array}$ & Dimension & Indicator & Measurement & Scale \\
\hline \multirow{3}{*}{$\begin{array}{l}\text { Work Environment } \\
\qquad\left(\mathrm{X}_{1}\right)\end{array}$} & \multirow{3}{*}{$\begin{array}{l}\text { Physical work } \\
\text { environment }\end{array}$} & - Lighting & - Lighting level & Ordinal \\
\hline & & - Temperature & - Temperature level & Ordinal \\
\hline & & - Humidity & - Humidity level & Ordinal \\
\hline \multirow{10}{*}{$\begin{array}{l}\text { Work environment is } \\
\text { the entire tools and } \\
\text { materials encountered, } \\
\text { the surrounding } \\
\text { environment in } \\
\text { which one is working, } \\
\text { working methods, } \\
\text { as well as the } \\
\text { arrangement works } \\
\text { both as individuals } \\
\text { and as a group. } \\
\text { Sedarmayati (2006:1) }\end{array}$} & & - Air circulation & - Air circulation level & Ordinal \\
\hline & & - Noise handling & - Noise handling level & Ordinal \\
\hline & & - Mechanical vibration & - Mechanical vibration level & Ordinal \\
\hline & & - Bad odor & - Bad odor level & Ordinal \\
\hline & & - Paint color in the workspace & - Paint color in the workspace level & Ordinal \\
\hline & & - Room setting & - Room setting level & Ordinal \\
\hline & Non-physical & - Nurse to nurse relationship & - Level of nurse to nurse relationship & Ordinal \\
\hline & $\begin{array}{llll}\mathrm{w} & \mathrm{o} & \mathrm{r} & \mathrm{k}\end{array}$ & - Employee to Superior relationship & - Level of employee to superior relationship & Ordinal \\
\hline & environment & - Promotion opportunities & - Promotion opportunities level & Ordinal \\
\hline & & - Work safety & - Work safety level & Ordinal \\
\hline
\end{tabular}




\begin{tabular}{|c|c|c|c|c|}
\hline $\begin{array}{l}\text { Compensation } \\
\left(\mathrm{X}_{2}\right)\end{array}$ & $\begin{array}{l}\text { F i n a n c i a l } \\
\text { compensation }\end{array}$ & $\begin{array}{l}\text { - Salary } \\
\text { - Insentive }\end{array}$ & $\begin{array}{l}\text { - Salary system level } \\
\text { - Insentive system level }\end{array}$ & $\begin{array}{l}\text { Ordinal } \\
\text { Ordinal }\end{array}$ \\
\hline \multirow{13}{*}{$\begin{array}{l}\text { Is the total } \\
\text { remuneration received } \\
\text { by the employee as } \\
\text { a substitute for the } \\
\text { services they have } \\
\text { offer. } \\
\text { (Mondy dan Noe, } \\
\text { 2008:4) }\end{array}$} & & - Overtime payment & - Overtime payment system level & Ordinal \\
\hline & & - Positional allowance & - Positional allowance system level & Ordinal \\
\hline & & - Health Allowance & - Health Allowance system level & Ordinal \\
\hline & & - Retirement & - Retirement program & Ordinal \\
\hline & Non-financial & - Interesting job & - Level of Interesting job & Ordinal \\
\hline & compensation & - Challenge & - Work challenge level & Ordinal \\
\hline & & - Responsibility & - Work responsibility level & Ordinal \\
\hline & & - Profit & - Level of profit in career development & Ordinal \\
\hline & & - Feedback & - Level of feedback from superior & Ordinal \\
\hline & & - Management treatment & $\begin{array}{l}\text { - Level of management treatment toward } \\
\text { employee }\end{array}$ & Ordinal \\
\hline & & - Open communication & $\begin{array}{l}\text { - Level of open communication between fellow } \\
\text { employees }\end{array}$ & Ordinal \\
\hline & & - Career guarantee & - Career guarantee obtained level & Ordinal \\
\hline & & - Organization support & - Work support level & Ordinal \\
\hline $\begin{array}{c}\text { Job Satisfaction } \\
\text { (Y) }\end{array}$ & Work itself & - Current work position & $\begin{array}{l}\text { - Level of current work position in accordance } \\
\text { with competence }\end{array}$ & Ordinal \\
\hline \multirow{7}{*}{$\begin{array}{l}\text { Based on the } \\
\text { perceptions, opinions } \\
\text { or views of employees } \\
\text { on work and its } \\
\text { aspects, namely } \\
\text { the advantages and } \\
\text { benefits that can } \\
\text { be provided by } \\
\text { employment and the } \\
\text { environment. } \\
\text { (Robbins, 2006:184) }\end{array}$} & $\begin{array}{l}\text { Salary and } \\
\text { promotion }\end{array}$ & - Salary and promotion imposed & - Level of salary and promotion imposed & Ordinal \\
\hline & $\begin{array}{l}\text { W o r k } \\
\text { condition }\end{array}$ & $\begin{array}{l}\text { - Availability of equipment that } \\
\text { support the implementation } \\
\text { of the work }\end{array}$ & - Level of availability of adequate equipment & Ordinal \\
\hline & $\begin{array}{l}\text { Collegues and } \\
\text { superiors }\end{array}$ & $\begin{array}{l}\text { - Consider the suggestion proposal } \\
\text { of subordinates }\end{array}$ & $\begin{array}{l}\text { - Level of always consider the suggestion } \\
\text { proposal of subordinates }\end{array}$ & Ordinal \\
\hline & & $\begin{array}{l}\text { - Familiarity between the superiors } \\
\text { and subordinates }\end{array}$ & - Level of leaders and superiors relationship & Ordinal \\
\hline & & - Reward for co-worker for their job & - Reward for co-worker for their job & Ordinal \\
\hline & & $\begin{array}{l}\text { - Fellow employees cooperate } \\
\text { facing difficulties }\end{array}$ & - Cooperation and teamwork level & Ordinal \\
\hline & $\begin{array}{l}\text { Suitability } \\
\text { b e t w e e n } \\
\text { work and } \\
\text { personality }\end{array}$ & $\begin{array}{l}\text { - Appropriate work placement and } \\
\text { in accordance with expertise }\end{array}$ & - Level of appropriate suitable work placement & Ordinal \\
\hline
\end{tabular}




\begin{tabular}{|c|c|c|c|c|}
\hline \multirow{15}{*}{$\begin{array}{l}\text { Extra Role } \\
\text { Behaviour } \\
\text { ( } Z \text { ) } \\
\text { Comprehensive } \\
\text { individual behavior, } \\
\text { not recognized } \\
\text { directly or explicitly } \\
\text { by the formal reward } \\
\text { system, and it was } \\
\text { jointly promote the } \\
\text { effective functioning } \\
\text { of the organization. } \\
\text { Organ in et.al } \\
\text { (Luthans, 2006:238) }\end{array}$} & \multirow{4}{*}{$\begin{array}{l}\text { Altruisme } \\
\text { (The behavior } \\
\text { of helping } \\
\text { others) }\end{array}$} & $\begin{array}{l}\text { - Willingness to help when } \\
\text { colleagues overwork }\end{array}$ & $\begin{array}{l}\text { - Level of willingness to help when colleagues } \\
\text { overwork }\end{array}$ & Ordinal \\
\hline & & $\begin{array}{l}\text { - Responsiveness to help overcome } \\
\text { the problems of co-workers }\end{array}$ & $\begin{array}{l}\text { - Level of responsiveness to help overcome } \\
\text { the problems of co-workers }\end{array}$ & Ordinal \\
\hline & & $\begin{array}{l}\text { - Cooperation with fellow } \\
\text { employees }\end{array}$ & - Level of cooperation with fellow employees & Ordinal \\
\hline & & - Trying to help resolve complaints & - Level of trying to help resolve complaints & Ordinal \\
\hline & \multirow{4}{*}{$\begin{array}{l}\text { Conscientious- } \\
\text { ness. } \\
\text { (Chariness) }\end{array}$} & - Carefulness at work & - Level of carefulness at work & Ordinal \\
\hline & & - Accuracy in work & - Level of accuracy in work & Ordinal \\
\hline & & - Adherence to work procedures & - Level of adherence to work procedures & Ordinal \\
\hline & & - Adherence to working hours & - Level of adherence to working hours & Ordinal \\
\hline & \multirow[t]{2}{*}{$\begin{array}{l}\text { Civic Virtue } \\
\text { (Concern) }\end{array}$} & $\begin{array}{l}\text { - Participation in activities / events } \\
\text { held by the Hospital }\end{array}$ & $\begin{array}{l}\text { - Level of participation in activities / events } \\
\text { held by the Hospital }\end{array}$ & Ordinal \\
\hline & & $\begin{array}{l}\text { - Concern for the surrounding } \\
\text { communities }\end{array}$ & $\begin{array}{l}\text { - Level of concern for the surrounding } \\
\text { communities }\end{array}$ & Ordinal \\
\hline & \multirow[t]{2}{*}{ Sportsmanship } & $\begin{array}{l}\text { - Sense of responsibility towards the } \\
\text { problem in the company }\end{array}$ & $\begin{array}{l}\text { - Level of sense of responsibility towards the } \\
\text { problem in the company }\end{array}$ & Ordinal \\
\hline & & $\begin{array}{l}\text { - Efforts to optimize creativity and } \\
\text { initiative to complete the work }\end{array}$ & $\begin{array}{l}\text { - Level of efforts to optimize creativity and } \\
\text { initiative to complete the work }\end{array}$ & Ordinal \\
\hline & \multirow{3}{*}{$\begin{array}{l}\text { Courtesy } \\
\text { (Politeness) }\end{array}$} & - Decency in behavior & - Level of decency in behavior & Ordinal \\
\hline & & - Freindliness in communication & - Level of freindliness in communication & Ordinal \\
\hline & & Personal integrity & - Personal integrity level & Ordinal \\
\hline
\end{tabular}

Table 4. Result of Regression Analysis of Work Environment and Compensation on Job Satisfaction

\begin{tabular}{|c|c|c|c|c|c|c|}
\hline \multicolumn{7}{|c|}{ Coefficients ${ }^{\mathrm{a}}$} \\
\hline \multirow[b]{2}{*}{ Model } & & \multicolumn{2}{|c|}{ Unstandardized Coefficients } & \multirow{2}{*}{$\frac{\text { Standardized Coefficients }}{\text { Beta }}$} & \multirow{2}{*}{$\mathrm{t}$} & \multirow{2}{*}{ Sig. } \\
\hline & & $\mathrm{B}$ & Std. Error & & & \\
\hline \multirow[t]{3}{*}{1} & (constant) & 1.352 & .459 & & 2.944 & .004 \\
\hline & $\mathrm{X}_{1}$ & .295 & .132 & .386 & 9.727 & .000 \\
\hline & $\mathrm{X}_{2}$ & .301 & .150 & .502 & 5.907 & .001 \\
\hline
\end{tabular}

a. Dependent Variable: $\mathrm{Y}$

Table 5. Result of Regression Analysis of Job Satisfaction on Extra Role Behavior

Coefficients(a)

\begin{tabular}{|c|c|c|c|c|c|c|}
\hline \multirow[b]{2}{*}{ Model } & & \multicolumn{2}{|c|}{ Unstandardized Coefficients } & \multirow{2}{*}{$\frac{\text { Standardized Coefficients }}{\text { Beta }}$} & \multirow{2}{*}{$\mathrm{t}$} & \multirow{2}{*}{ Sig. } \\
\hline & & $\mathrm{B}$ & Std. Error & & & \\
\hline \multirow[t]{2}{*}{1} & (constant) & ,308 & 1.690 & & .182 & .856 \\
\hline & $\mathrm{X}$ & .287 & .088 & .840 & 15.596 & .002 \\
\hline
\end{tabular}

a. Dependent Variable: $Y$

Table 6. Result of Coefficient of Determination of Job Satisfaction on Extra Role Behavior

Model Summary

\begin{tabular}{|c|c|c|c|c|}
\hline Model & R & R Square & Adjusted R Square & Std. Error of the Estimate \\
\hline 1 & $.840 \mathrm{a}$ & .705 & .5422 & 2.3167 \\
\hline
\end{tabular}




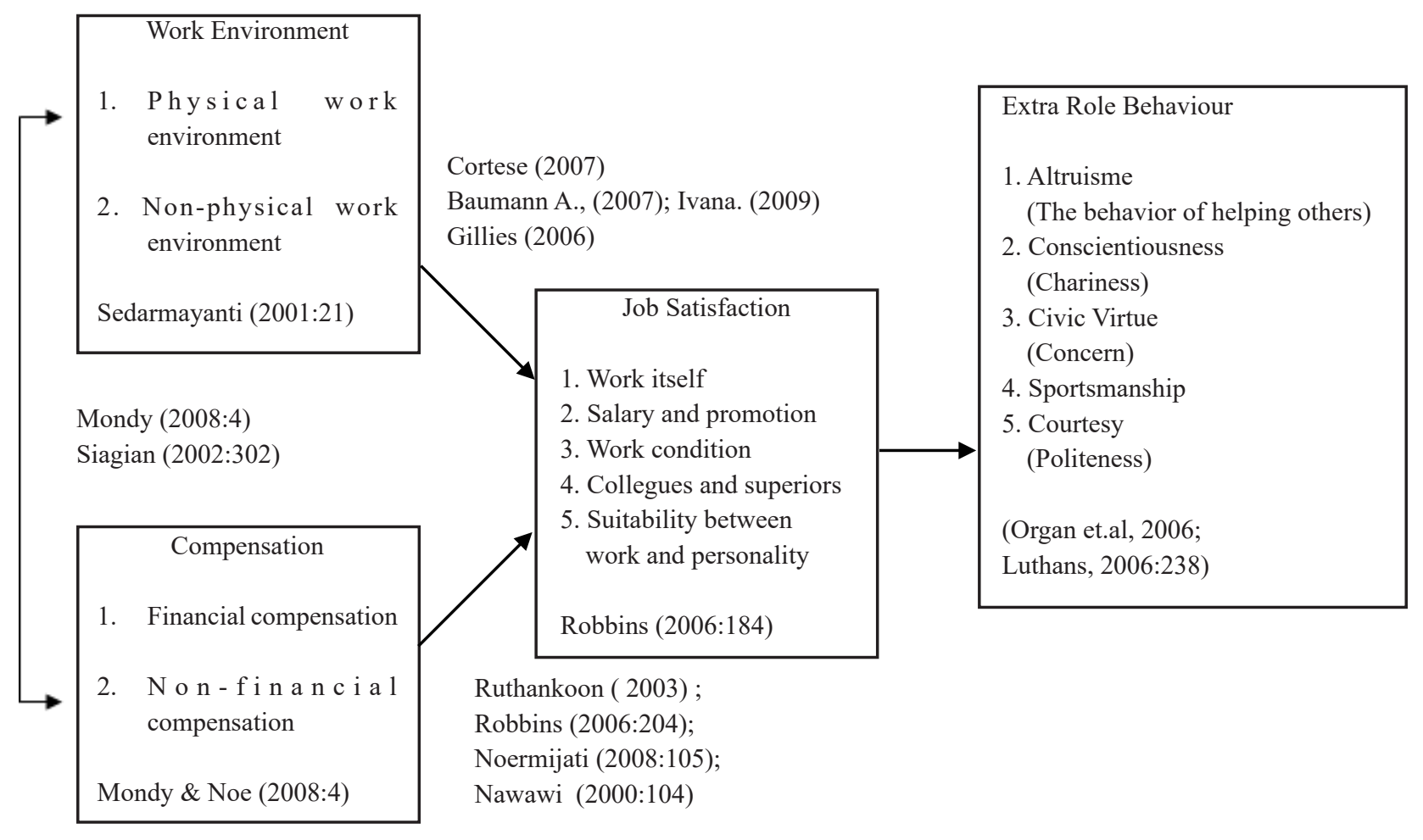

Figure. 1 Research Paradigm

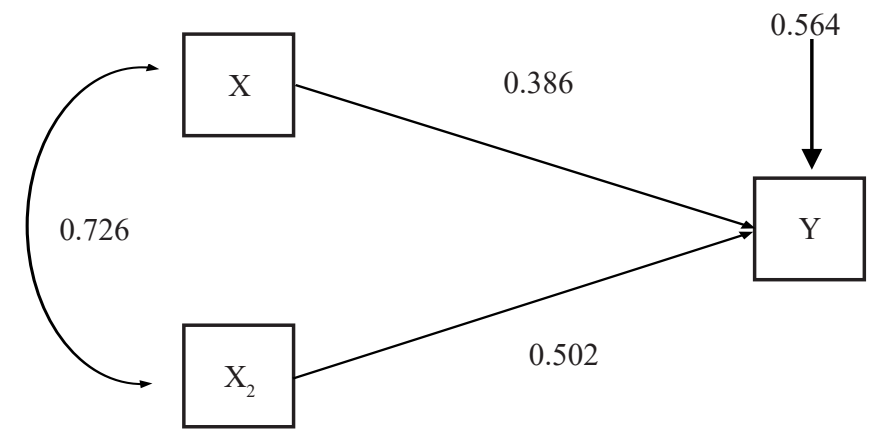

Figure 2. Path Diagram and Coeficient of the Effect of Work Environment $\left(\mathrm{X}_{1}\right)$ and Compensation $\left(\mathrm{X}_{2}\right)$ on Job Satisfaction $(\mathrm{Y})$

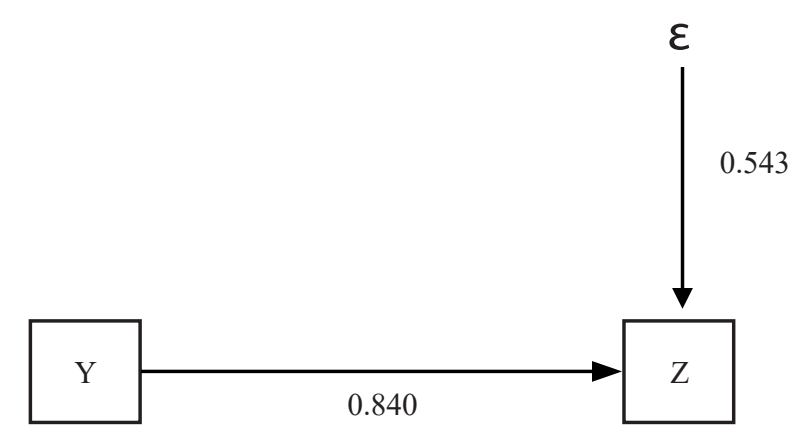

Figure 3. The Relationship between Job Satisfaction and Extra Role Behaviour Structure 